\title{
Ribosomal RNA synthesis and function as influenced by amino acid supply and stress
}

\author{
By R. W. WanNemacher Jr, US Army Medical Research Institute of Infectious \\ Diseases, Frederick, Maryland 21701, USA, and Bureau of Biological Research, \\ Rutgers College, New Brunswick, New fersey 08903, USA
}

For several years many investigators have been trying to define the possible basic control mechanism for regulating the rates of protein synthesis in different tissues of animals given varying protein intakes. As molecular biology evolved it became obvious that control mechanisms were related to the synthesis and utilization of ribosomes and messenger RNA. Munro (1970) has pointed out the problems of relating free amino acid pool size to the regulation of protein and RNA synthesis within the cells of mammalian organisms. The intracellular concentrations of free amino acids are an algebraic sum of the rates of dilution with endogenous amino acids, transport to and from extracellular space, utilization for synthesis of proteins and other metabolites, synthesis of non-essential amino acids from precursors within the cell, and amino acid degradation. Despite these obvious difficulties, significant correlations have been reported between the cellular free amino acid concentrations and rates of protein and RNA synthesis in liver (Cooper, Muramatsu, Wannemacher \& Leathem, 1968; Wannemacher, Wannemacher, \& Yatvin 1971), ventricular myocardium (Wannemacher \& McCoy, 1969) and skeletal muscle (Cooper, Wannemacher \& Raica, 1969). To develop this concept of relationship between cellular free amino acids and rate of RNA synthesis the present information will be discussed in the following categories: (a) effects of short-term alterations in amino acid supply; (b) acute dietary or hormonal depletion of cellular free amino acid pools; and (c) dietary and stress related increases in flow or concentrations, or both, of cellular free amino acids.

\section{Short-term alterations in amino acid supply}

Elwyn (1970) observed marked increases in concentration of free amino acids in the portal vein after a meal, but the changes in arterial amino acids were inconsistent and reflected a change in balance between liver uptake and peripheral output of amino acids. Thus, the liver appears to play the main role in taking up many of the amino acids which enter the portal vein after a meal. The observations of several investigators (Fleck, Shepherd \& Munro, 1965; Sox \& Hoagland, r966; Webb, Blobel \& Potter, 1966; Wunner, Bell \& Munro, 1966; Sidransky, Bongiorno, Sarma \& Verney, 1967 ) have indicated that, in animals starved for $18-24 \mathrm{~h}$, the 
ingestion of either a protein or complete amino acid mixture results in a rapid increase in the degree of hepatic ribosomal aggregation and rate of protein synthesis. Further, integrity of the polyribosomes and rate of protein synthesis was dependent on amino acid concentrations both in an in vitro system (Baliga, Pronczuk \& Munro, I968; Wannemacher, Cooper \& Muramatsu, 1970) and in perfused liver (Jefferson \& Korner, 1969). Though the omission of several different essential amino acids could prevent the increased rate of amino acid incorporation and reduce the polyribosomal reaggregation in an in vitro amino acid incorporating system (Baliga et al. I g68), only the omission of dietary tryptophan from an ingested mixture of amino acids prevented this response from taking place in the experimental animal (Fleck et al. 1965; Wunner et al. I966; Sidransky, Sarma, Bongiorno \& Verney, r968).

During periods of decreased amino acid supply, hepatic RNA concentrations are reduced (Clark, Naismith \& Munro, 1957), RNA catabolism is increased (Enwonwu \& Munro, 1970), and a larger portion of the ribosomal population is held in subunit form (Wunner et al. 1966). Thus, the hypothetical model developed by Munro ( 1966 ) suggests that a decrease in amino acid supply will result in a disaggregation of the polyribosomal profile, an accumulation of subunits of ribosomal degradation, and a marked decrease in the ability of polyribosomes to synthesize protein. Continued amino acid deprivation will result in a decreased synthesis of liver RNA (Enwonwu \& Munro, 1970). An increase in the amino acid supply will reverse this process resulting in an increase in polysomal aggregates, and rates of protein and RNA synthesis.

Though the short-term alterations in dietary amino acid supply do affect the rate of amino acid movement into liver (Elwyn, I970) only very small and transient changes are noted in the intracellular concentration of free amino acids (Wannemacher \& Allison, I968; Munro, 1970). Therefore, more severe amino acid deprivation or hormonal imbalances had to be utilized to study the effects of a reduced cellular amino acid pool on the RNA and protein synthetic rates of a tissue.

\section{Effects of acute decreases in amino acid supply on $R N A$ and protein synthesis}

In the first study, male rats weighing about $200 \mathrm{~g}$, who were litter-mates, were placed in pair-weighted groups and pair-fed with either $18 \%$ casein diet (controls) (Allison, Wannemacher, Banks \& Wunner, 1964), or a protein-free diet (PFD), or they were hypophysectomized (HYPOX) and given an $18 \%$ casein diet for $28 \mathrm{~d}$. In the HYPOX and protein-depleted rats the total liver free amino acids were reduced to 35 and $56 \%$ respectively of that found in the pair-fed controls (Fig. I). Thus, by the chronic giving of a diet devoid of amino acids or in hypophysectomized rats given an adequate protein diet, it was possible to significantly reduce the pool of liver free amino acids. In addition, the concentrations of total ribosomes and the in vitro protein synthetic incorporation rate of the ribosomes were reduced to below $50 \%$ of control values (Fig. 1 ). Individual free amino acids in liver were divided into three groupings: (a) the eleven amino acids which Jefferson \& Korner ( 1969 ) found to be essential for hepatic protein synthesis; (b) the remaining non-essential free amino acids in the hepatic pool; and (c) the total free amino acid content of the 


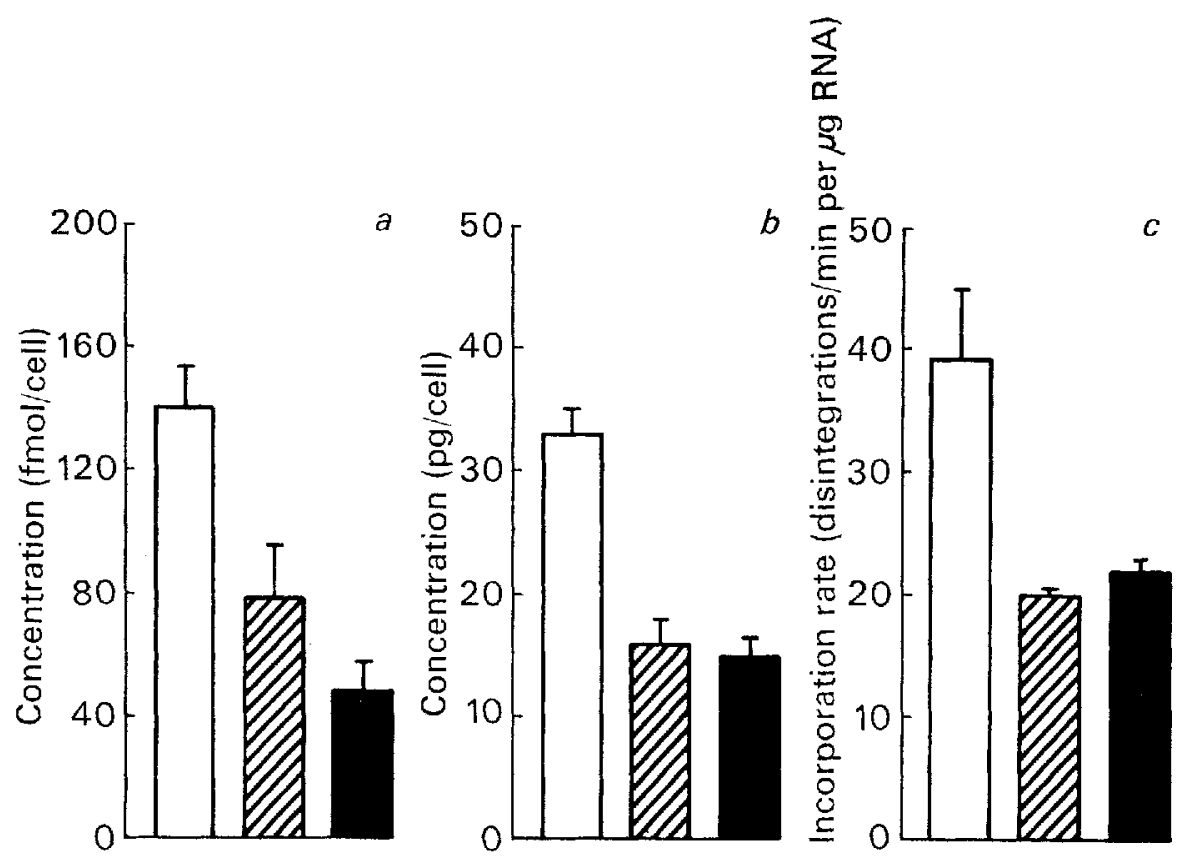

Fig. I. Concentration of (a) cellular free amino acids, (b) total ribosomes, and $(c)$ in vitro rate of amino acid incorporation into liver of animals which were given an $18 \%$ casein diet (open columns), intact rats which were given a protein-free diet (hatched columns), or hypophysectomized rats which were given $18 \%$ casein (solid columns) for $28 \mathrm{~d}$. Each value is the mean for eight rats; the vertical bars represent the standard errors. Tissue free amino acids, total ribosome for RNA, and amino acid incorporation rate were done by a previously described procedure (Wannemacher, Wannemacher et al. 197I).

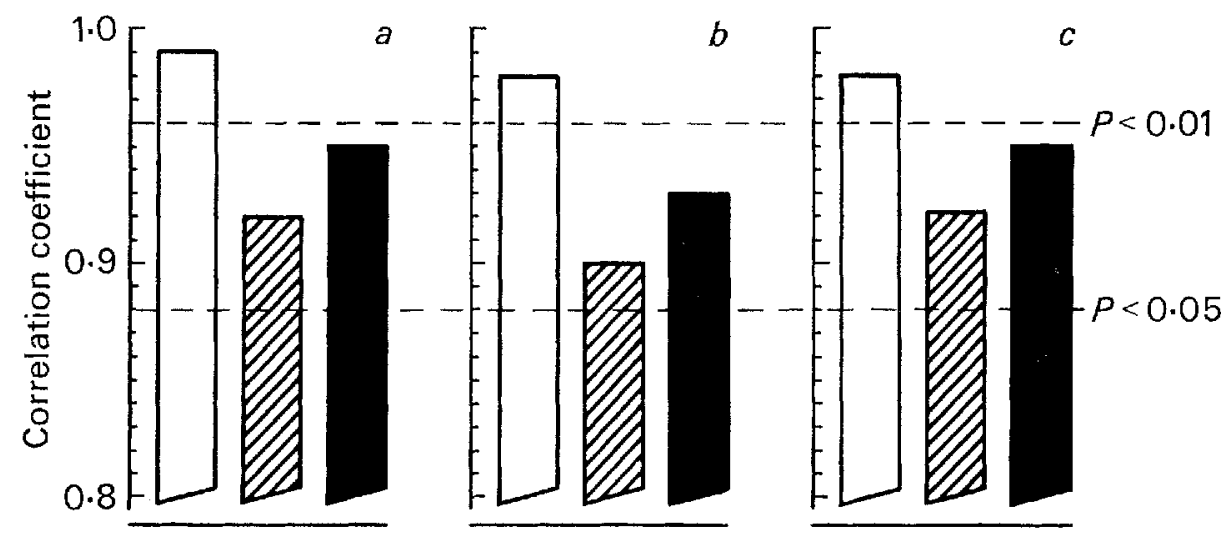

Fig. 2. Correlation coefficient between cellular essential amino acid concentrations (open columns), cellular non-essential amino acids (hatched columns), or total cellular amino acids content (solid columns) and (a) total ribosomal RNA, (b) amino acid incorporation rate or (c) protein synthetic competence in liver of animals that had been given an $18 \%$ casein diet, intact rats which were given a protein-free diet, or hypophysectomized rats which were given an $18 \%$ casein diet for $28 \mathrm{~d}$. Each bar represents the correlation among twenty-four different determinations. 
liver. These values were plotted against either the total ribosomal RNA content of the liver, or rate of in vitro amino acid incorporation, or protein synthetic competence (a product of the total cellular ribosomal RNA and rate of in vitro amino acid incorporation). Correlation coefficients were determined for each one of these measurements and are illustrated in Fig. 2; values for $P$ are also shown. All correlations were significant $(P<0.05)$ and when comparisons were made against the essential amino acid concentrations the probabilities were less than 0.0 . for all three determinations of RNA and protein synthetic ability of the hepatocytes. These results support the hypothesis that amino acids can affect both the rate of RNA synthesis and the protein synthetic ability of the liver ribosomes.

When weanling $(23-\mathrm{d}$-old) male rats were fed on either an amino acid-deficient diet $(6 \%$ casein) or on a diet containing an adequate amount of protein (controls) ( $18 \%$ casein) for $28 \mathrm{~d}$, the hepatic cells from the rats fed on the low-protein diet were characterized by a decrease in essential free amino acids to $28.3 \%$ and non-essential amino acids to $47.8 \%$ of the respective values found in rats fed on the higher protein diet (Wannemacher, Cooper \& Yatvin, I968). In addition, compared with cells from the control rats, the hepatic cells from the animals fed on the amino acid deficient diet were characterized by almost complete inhibition of cell proliferation and a marked decrease in cell volume, protein content, and concentration of cytoplasmic RNA. A good correlation was observed between the in vivo rate of hepatic protein synthesis and both the cellular protein and essential free amino acid content of the liver (Wannemacher, Wannemacher et al. I97 I). A similar correlation was observed between the concentration of individual free amino acids that are essential for protein synthesis and the cellular concentration of ribosomal RNA. Thirty minutes after a pulse-dose of $\left[{ }^{3} \mathrm{H}\right]$ uridine the incorporation of tritium into total RNA of the hepatocytes from the amino acid deprived rats was twice that observed in liver cells from rats given an adequate diet. The total RNA half-life was not affected by giving the amino acid-deficient diet, and both the magnesium and manganese plus salt RNA-polymerase activities were significantly increased in the rats given the $6 \%$ casein. However, when the distribution of radioactivity in the RNA of the nucleus and ribosomes of the cytoplasm was followed sequentially for $\mathrm{I} 2 \mathrm{~h}$ after a dose of $\left[{ }^{3} \mathrm{H}\right]$ uridine, the ribosomal RNA fraction in the hepatocytes from the rats given the amino acid deficient diet contained about half the amount of radioactivity of ribosomes from rats given an adequate protein intake (Wannemacher, Wannemacher et al. I97I). From these results it was concluded that amino acids influence RNA synthesis by inhibiting the rate of synthesis of new ribosomes. A similar effect of amino acids on rate of appearance of newly synthesized ribosomal subunits in the cytoplasm of Landschutz cells has been observed by Shields \& Korner (1970). These authors explain their results by suggesting that amino acid starvation exerts its effects through an inhibition of synthesis of proteins with a rapid rate of turnover which is required for ribosomal synthesis. A similar mechanism may explain how the concentration of amino acids can regulate the rate of synthesis of ribosomes in liver cells.

From the results presented in the above studies there appeared to be some 

regulatory mechanism whereby a reduction in the supply and concentration of essential hepatic free amino acids could control the rate of ribosomal RNA release and its utilization in the cytoplasm. This reduction in supply of amino acids to a tissue could represent either dietary effects or hormonal influences on the transport of the amino acids into the cells of the target tissue. Subsequently, the question was raised as to whether an increase in amino acid supply to a particular cell would stimulate the synthesis of ribosomal RNA and proteins. Therefore, the following discussion will be devoted to observations on experiments designed to study the effects of increased amino acid supply on RNA and protein synthesis.

Dietary and stress related increases in flow or concentration of cellular free amino acids, or both

When weanling, male rats were given varying amounts of casein nitrogen for $28 \mathrm{~d}$, a maximum rate of gain in body-weight was obtained in rats given approximately $2 \mathrm{~g} \mathrm{~N} / \mathrm{d}$ per kg body-weight; higher intakes of casein $\mathrm{N}$ resulted in a slight depression in the rate of growth (Allison $e$ al. 1964 ). In contrast, the growth rate of liver cells continued to increase even when the rats consumed as much as $7^{-8} \mathrm{~g}$ casein $\mathrm{N}$. Similarly, cellular essential free amino acids were also correlated with the intake of dietary casein. A significant correlation was observed when cellular RNA or in vivo rates of protein synthesis were plotted against the corresponding essential free amino acid content of the liver cells (Fig. 3). These results suggest that continual giving of an excess supply of dietary amino acids will result in significant increases

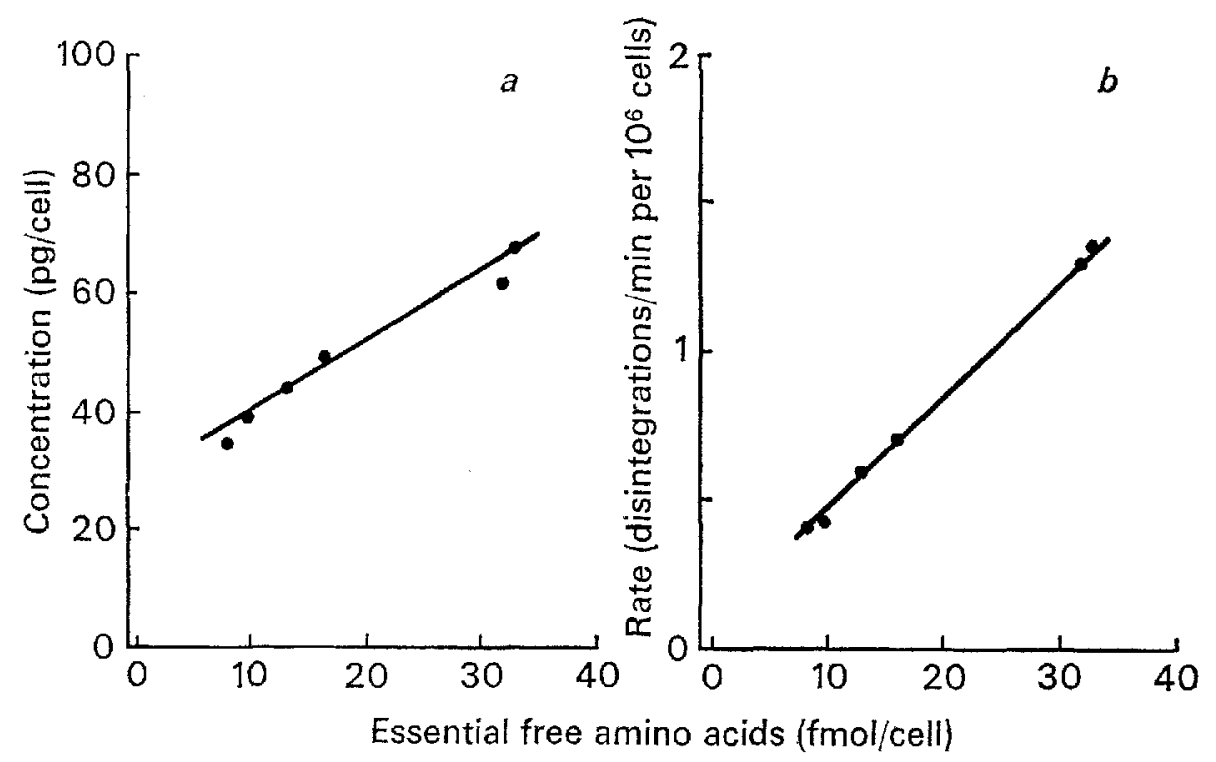

Fig. 3. A plot of concentration of $(a)$ hepatic cellular RNA and (b) rate of in vivo protein synthesis against the essential free amino acid concentration in liver of rats given varying amounts of casein nitrogen for $28 \mathrm{~d}$. Each point is the mean for eight animals. Cellular RNA concentrations and rate of in vivo protein synthesis were determined by previously described procedures (Wannemacher, Wannemacher et al. 1971). 
in the pool size of the hepatic free amino acids, especially those amino acids which are associated with the regulation of protein synthesis.

Various stresses, such as infection and injury, have been shown to have a marked effect on the distribution of amino acids in various tissues of the host (Munro, 1970; Feigin, Beisel \& Wannemacher, 1971). Therefore, studies were initiated to determine whether a similar correlation could be observed between the concentration or flow of cellular amino acids, or both, and rate of RNA and protein synthesis in (a) hypertrophic hearts, (b) liver of tumour-bearing animals, and (c) liver during extrahepatic inflammatory processes.

When female rats are unilaterally nephrectomized, injected with $2.5 \mathrm{mg}$ deoxycorticosterone acetate, and given $\mathrm{I} \%$ sodium chloride in their drinking-water, they developed hypertension but ventricular weight was markedly increased Wannemacher \& $\mathrm{McCoy}, \mathrm{I} 969$ ). In contrast, the rate of transport and concentration of free amino acids in the hypertrophic heart was increased to twice that found in dietary controls. When the rate of in vitro protein synthesis or concentration of heart RNA was plotted against the concentrations of free amino acids in the heart a significant correlation was observed (Fig. 4). Thus, the results suggested that the increased movement of amino acids into the heart during steroid induced hypertrophy could be related to the increased rate of RNA and protein synthesis.

When male rats were implanted with the Walker 256 carcinosarcoma and killed I $5 \mathrm{~d}$ later, the weight of liver in the tumour-bearing rats was significantly greater than that in pair-fed controls (Wannemacher \& Yatvin, 1965). The increase in liver weight was associated with raised concentrations of cellular RNA and essential free

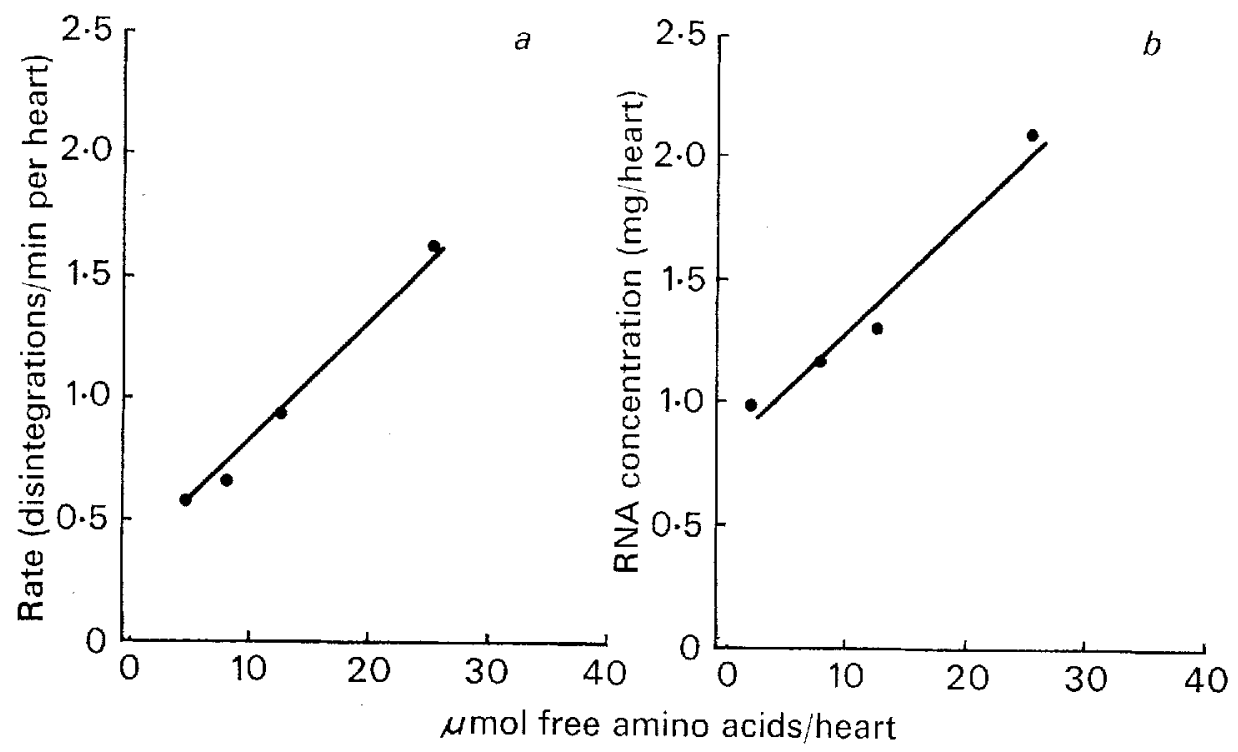

Fig. 4. A plot of $(a)$ the in vivo rate of a cardiac protein synthesis and $(b)$ concentration of heart RNA plotted against the concentration of free amino acids in the heart. Each value is the mean for eight animals. The determinations of the in vivo rate of protein synthesis and RNA content of the heart were made by previously described procedures (Wannemacher \& McCoy, r969). 


\section{Vol. 31 Amino acid supply and polynucleotide and protein metabolism 287}

amino acids. The results lend credence to the hypothesis that stress-related stimulus of amino acid movement into a target tissue such as liver can result in a significant increase in RNA and protein synthesis. In addition, when synthesis of serum albumin and globulin was compared in the tumour-bearing and control animals, there was a significant decrease in the synthesis of albumin and a doubling of the increase in the synthesis of serum globulin in the tumour-bearing rats (Fig. 5). Thus, the flux of amino acids into a tissue appears to be able to influence the pattern of protein synthesis within the cells of the target tissue.
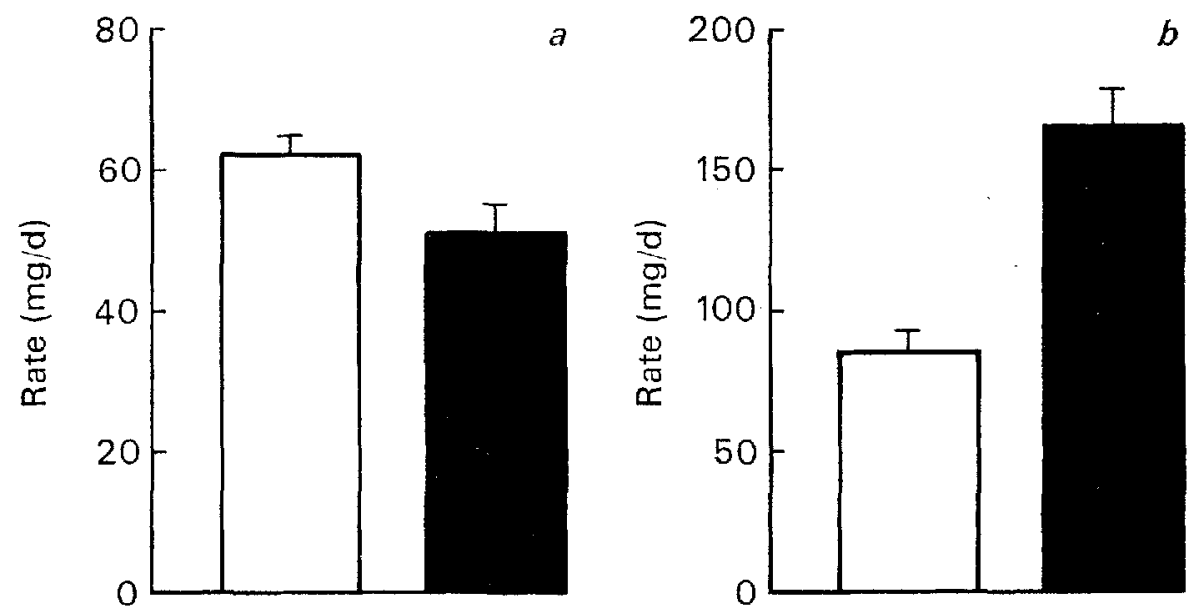

Fig. 5. Rate of serum albumin (a) and globulin synthesis $(b)$ in control (open columns) and experimental animals, I $5 \mathrm{~d}$ after implantation of Walker 256 carcinosarcoma (solid columns). Each column represents the mean for eight animals; the vertical bars represent the standard errors. Serum albumin and globulin syntheses were determined by previously described procedures (Wannemacher \& Yatvin, 1965).

From prospective studies in volunteers infected with either bacteria or virus, it was concluded that plasma amino acids were depressed very early in the process of infection, and that the magnitude and duration of the depression was correlated with degree and duration of the febrile response (Wannemacher, Pekarek, Bartelloni, Vollmer \& Beisel, 1972). These changes in plasma free amino acids could not be explained by infection-related anorexia or by later increases in excretion of urinary $\mathrm{N}$. It was observed that unusually large quantities of certain plasma amino acids were taken up by cells of liver and rapidly utilized for serum protein synthesis (Wannemacher, Powanda, Pekarek \& Beisel, 1971). If the serum of infected rats was separated by electrophoresis and the radioactivity of individual fractions was determined, most of the infection-related increase in protein synthesis was found in the $\alpha_{1^{-}}, \alpha_{2^{-}}$, and $\beta$-globulins, with a decrease in the synthesis of albumin (Powanda, Wannemacher \& Cockerell, 1972). Similar changes in amino acid flux and serum protein synthesis were also observed in rats with turpentine abscesses (Cockerell, 1972). Thus, during this model infection it was possible to demonstrate an increased flux and utilization of amino acids by tissue and subsequently raised rates of synthesis of specific serum proteins. 
At $\mathrm{I} 6 \mathrm{~h}$ post-exposure to Streptococcus fneumoniae, the liver of infected rats contained significantly more RNA and bound ribosomal RNA but a decrease in the amount of free ribosomal RNA. Thirty minutes after giving the same rats a pulsedose of $\left[{ }^{14} \mathrm{C}\right]$ orotic acid the specific activity of the total liver RNA and total ribosomal RNA fractions were double in the infected rats compared to the pair-fed controls but no difference could be seen in the specific activity of a nuclear RNA, which would rule out the possibility of changes in precursor pool size (Fig. 6). When the distribution of labelled RNA fractions was studied up to $4 \mathrm{~h}$ after an injection of $\left[{ }^{14} \mathrm{C}\right]$ orotic acid, there was a more rapid loss of activity from the nuclear RNA in the livers from infected rats and a marked increase in the rate of accumulation in bound ribosomal RNA as compared to pair-fed controls (Fig. 7). These observations support the hypothesis that the stress-related flux of amino acids to liver is correlated with a marked increase in the synthesis of both RNA and protein. In addition, the pattern of protein synthesis appears to be governed by the flux of amino acids and is perhaps related to the type or RNA that is being synthesized in the stimulated cells. In the liver of infected rats the major increase in RNA synthesis was observed in the bound ribosomes, which have been shown by several investigators to be associated with the synthesis of proteins for transport from the liver cells (Hicks, Drysdale \& Munro, 1969; Redman, 1969). Whether this represents the synthesis of new messenger, utilization of stable messenger or the synthesis of the so-called 'Memoron' type ribosomes (Pitot, 1969) is unknown at the present time. Preliminary results from our laboratory, however, would suggest that very early in the infectious process there is a significant increase in the activity of the chromatin template
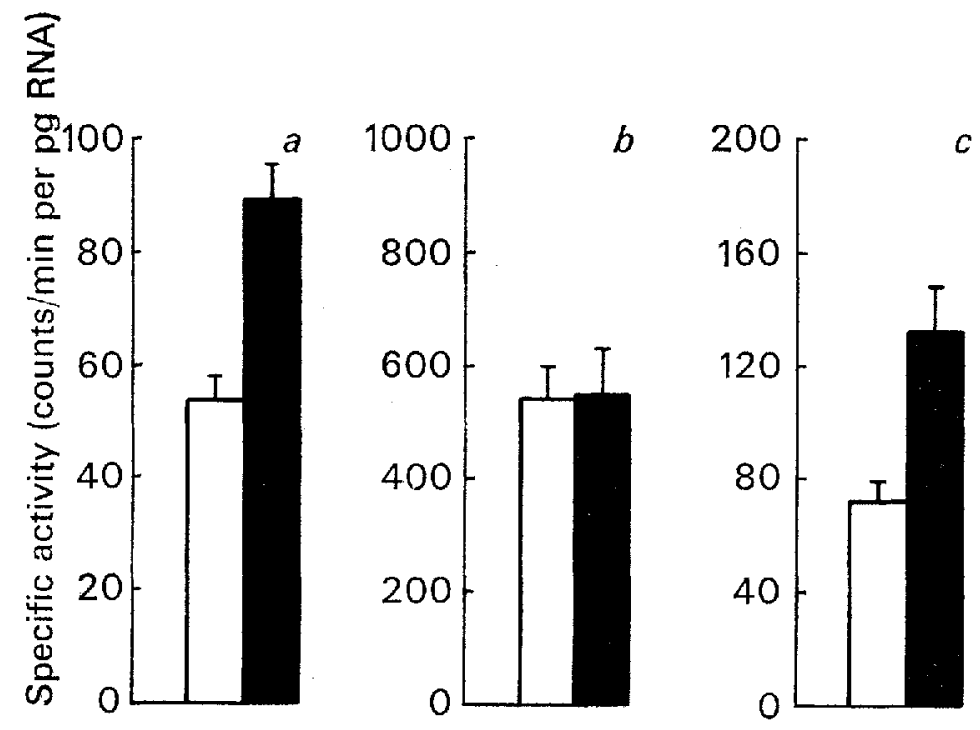

Fig. 6. Specific activity of $(a)$ total hepatic, $(b)$ nuclear and $(c)$ ribosomal RNA 30 min after a pulsedose of $\left[{ }^{14} \mathrm{C}\right]$ orotic acid in control (open columns) and rats exposed $\mathrm{r} 6 \mathrm{~h}$ earlier to Streptococcus pneumoniae (solid columns). Each value is the mean for six animals; the vertical bars represent the standard errors. Previously described procedures were used for the measurement of orotic acid uptake and fractionation of cellular RNA (Wannemacher, Wannemacher et al. 1971). 

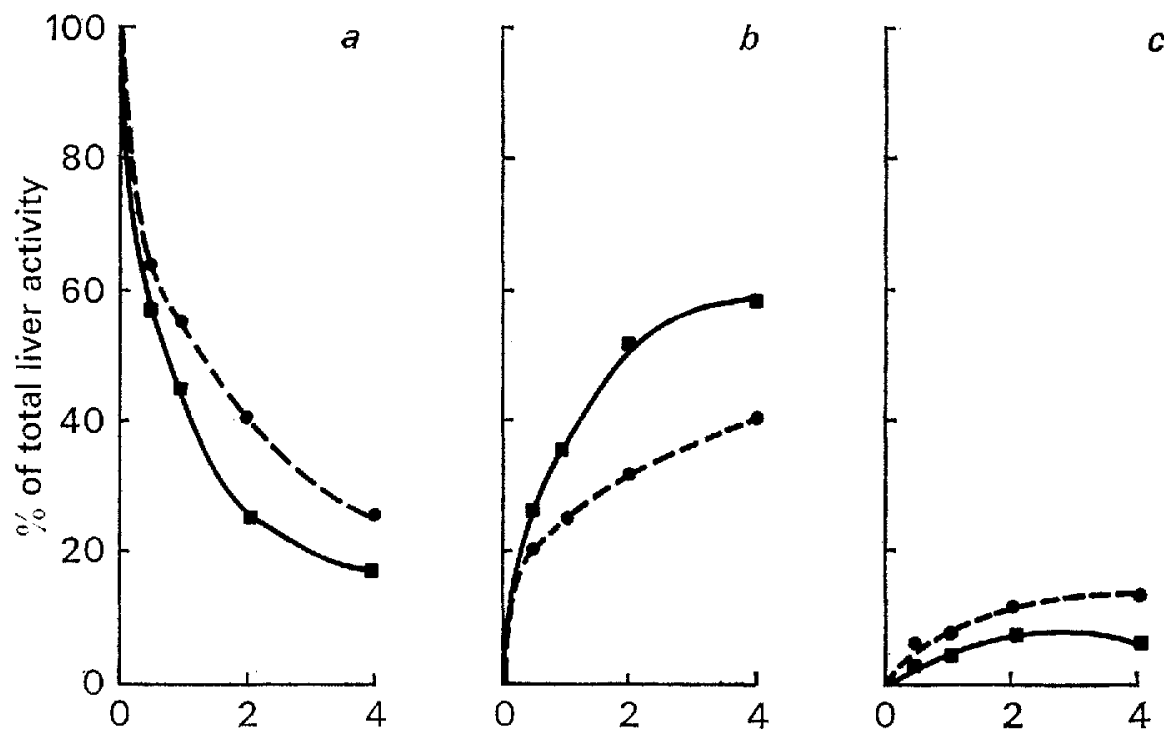

Time after injection (h)

Fig. 7. Percentage distribution of radioactivity in (a) nuclear, (b) bound ribosomal, and (c) free ribosomal RNA at various times after a dose of $\left[{ }^{14} \mathrm{C}\right]$ orotic acid in pair-fed controls $(x---x)$ in animals exposed to Streptococcus pnetmoniae $(\times-\times) \perp 6 \mathrm{~h}$ before injection of the precursor. Calculations of cellular distribution of radioactive RNA and fractionation were made by previously described procedures, (Wannemacher, Wannemacher et al. 1971).

activity from the liver of mice exposed to S. pneumoniae (Steinhart, 1971). Studics are currently in progress to determine the possible relationship betwcen the amino acid flux and the type of RNA-directed protein synthesis that is taking place during various stresses in experimental animals.

\section{Conclusions}

Results have been presented which demonstrate the effects of dietary supply, hormonal deficiencies or physiological stress on concentration or flux or both of free intracellular amino acids in the cells of target tissues. The changes in intracellular free amino acid concentrations or flux correlate positively with the rates of RNA and protein synthesis within those cells. In addition, there is a relationship between the cellular free amino acid pool size and the pattern of protein synthesis which is observed in each of the particular tissues studied. The exact mechanism by which the cellular amino acids can influence RNA and protein synthesis has not been completely elucidated. There are, however, results which indicate that the amino acids may influence (a) the chromatin activity for specific operons; (b) the synthesis of proteins which are associated with ribosomal RNA release; and (c) the utilization of preformed stable messenger RNA operons. Further studies in both in vivo and in vitro systems will be necessary to elucidate the mechanism by which amino acids can influence the cellular pattern of RNA and protein synthesis. 
In conducting the research described in this report, the investigators adhered to the Guide for Laboratory Animal Facilities and Care, as promulgated by the Committee on the Guide for Laboratory Animal Facilities and Care of the Institute of Laboratory Animal Resources, National Academy of Sciences-National Research Council. The facilities are fully accredited by the American Association of Accreditation of Laboratory Animal Care.

\section{REFERENCES}

Allison, J. B., Wannemacher, R. W. Jr, Banks, W. L. Jr \& Wunner, W. H. (1964). 7. Nutr. 84, $3^{83}$.

Baliga, B. S., Pronczuk, A. W. \& Munro, H. N. (1968). F. molec. Biol. 34, 199.

Clark, C. M., Naismith, D. J. \& Munro, H. N. (1957). Biochim. Biophys. Acta 23, 587.

Cockerell, G. L. (1972). Fedn Proc. Fedn Am. Socs exp. Biol. 31, 7 ro.

Cooper, W. K., Muramatsu, K., Wannemacher, R. W. Jr \& Leathem, J. H. (1968). Fedn Proc. Fedn Am. Socs exp. Biol. 27, 415.

Cooper, W. K., Wannemacher, R. W. Jr \& Raica, N., Jr (1969). Fedn Proc. Fedn Am. Socs exp. Biol. 28,755 .

Elwyn, D. H. (1970). In Mammalian Protein Metabolism Vol. 4, p. 523 [H. N. Munro, editor]. New York, NY: Academic Press.

Enwonwu, C. O. \& Munro, H. N. (1970). Archs Biochem. Biophys. 138, 532.

Feigin, R. D., Beisel, W. R. \& Wannemacher, R. W. Jr (I97 1). Am. F. clin. Nutr. 24, 329.

Fleck, A., Shepherd, J. \& Munro, H. N. (1965). Science, N.Y. 150, 628.

Hicks, S. J., Drysdale, J. W. \& Munro, H. N. (1969). Science, N.Y. 164, 584.

Jefferson, L. S. \& Korner, A. (1969). Biochem. F. х1r, 703.

Munro, H. N. (1966). Nutritio Dieta. 8, 179.

Munro, H. N. (1970). Mammalian Protein Metabolism Vol. 4, p. 299 [H. N. Munro, editor]. New York, NY: Academic Press.

Pitot, H. C. (1969). Archs Path. 87, 212.

Powanda, M. C., Wannemacher, R. W. Jr \& Cockerell, G. L. (1972). Fedn Proc. Fedn Am. Socs exp. Biol. 3r, 710 .

Redman, C. M. (1969). Fedn Proc. Fedn Am. Socs exp. Biol. 28, 726.

Shields, R. \& Komer, A. (1970). Biochim, biophys. Acta 204, 52 I.

Sidransky, H., Bongiorno, M., Sarma, D. S. R. \& Verney, E. (1967). Biochem. biophys. Res. Commun. $27,242$.

Sidransky, H., Sarma, D. S. R., Bongiorno, M. \& Verney, E. (1968), F. biol. Chem. 243, 1123.

Sox, H. C. Jt \& Hoagland, M. B. (I g66). F. molec. Biol. 20, I 13 .

Steinhart, W. L. (I971). Proc. Soc. exp. Biol. Med. 137, 619.

Wannemacher, R. W. Jr \& Allison, J. B. (I968). In Protein Nutrition and Free Amino Acid Patterns p. 187 [J. H. Leathem, editor]. New Brunswick, NJ: Rutgers University Press.

Wannemacher, R. W. Jr, Cooper, W. K. C. \& Muramatsu, K. (I97o), Proc. Soc. exp. Biol. Med. 135, 180.

Wannemacher, R. W. Jr, Cooper, W. K. C. \& Yatvin, M. B. (1968). Biochem. F. 107, 615.

Wannemacher, R. W. Jr \& McCoy, J. R. (r969). Am. f. Physiol. 216, 781.

Wannemacher, R. W. Jr, Pekarek, R. S., Bartelloni, P. J., Vollmer, R. T. \& Beisel, W. R. (1972). Metabolism 2r, 67.

Wannemacher, R. W. Jr, Powanda, M. C., Pekarek, R. S. \& Beisel, W. R. (I971). Infec. Immun. 4, 556.

Wannemacher, R. W. Jr, Wannemacher, C. F. \& Yatvin, M. B. (197I). Biochem. F. 124, 385 .

Wannemacher, R. W. Jr \& Yatvin, M. B. (1965). F. Nutr. 85, 393.

Webb, T. E., Blobel, G. \& Potter, V. R. (I 966). Cancer Res. 26, 253.

Wunner, W. H., Bell, J. \& Munro, H. N. (r966). Biochem. F. ror, 417. 